\title{
Current Condition of Private Security Industry in Mongolia
}

\author{
Galbat Lkhagvamaa \\ Law Enforcement University of Mongolia \\ Ulaanbaatar, Mongolia \\ Ju-Lak Lee (Corresponding Author) \\ julaklee@hanmail.net \\ Department of Security Management \\ Kyonggi University, Suwon, Republic of Korea
}

\begin{abstract}
Since 1990, with its transition to the market economy relations and with its newly built economic sector based on private ownerships, the private security sector has been developed in keeping with international best practices and standards in terms of its legal basis, structure and organization and, equipment and technology. The main objective of this study was to analyse current condition of private security in Mongolia and findings show that, in general, the security service in Mongolia is being developed with the two types of security service including the proprietary service and the contract service. The findings of the research give quite a complex picture of the development of private security in terms of current condition of private security in Mongolia. Therefore, the findings can be used to influence certain roles within the private security sector, but also to aid the development of the new strategic document on the further expansion of the private security industry in Mongolia which state policymakers will prepare.
\end{abstract}

Keywords: Private Security; Proprietary Security Service; Contract Security Service, Mongolia

\section{INTRODUCTION}

Since 1990, with its transition to the market economy relations and with its newly built economic sector based on private ownerships, Mongolia increasingly faced the imperatives and challenges to create a quite new system to ensure private security protection for providing the security and safety guarantees for organizations, individual citizens, business people, their lives and health, personal immunities, property and to create a safe business environment. As such, the private security sector has been developed in keeping with international best practices and standards in terms of its legal basis, structure and organization and, equipment and technology [1].

As an example, the Law on Contracted Private Security Service of Mongolia was enacted in 2000 that has ever since been revised twice in 2001 and in 2005. With the gradual improvement of the legal environment thanks to the new regulations for the development of the private security sector, at the beginning of the 2010s there were registered a total of 345 private security companies that employed a total of 5366 security officers and guards [2]. As such, the private security became an active player on the overall security market of Mongolia. This study aims to analyze current conditions of private security in Mongolia.

PRIVATE SECURITY SERVICES IN MONGOLIA

The private security system itself in Mongolia is constituted from the two categories, namely: 
- The proprietary security service which is being created by the business owners within the organizational structure of their corporations and companies so as to ensure the security and safety of their own activities.

- The contract security companies which operate on the basis of the contractual agreements established with their clients to protect their private security and safety [3].

The first category of the private security system/concept or the above said the proprietary security service is meant a security entity mostly created by both the biggest state owned and private owned business corporations and companies, including those major corporations and companies with foreign investments within the organizational structure of the corporations and companies concerned so as to ensure the security and safety of their own operations and property.

At this moment, there are comparatively fewer companies or corporations that ensure their own private security and safety under this category of the private security concept called as the proprietary security service. The companies or corporations ensuring their security and safety under this concept are those that have a strong position on the market and a self-reliant financial standing recognized as being the national major business entities like the Mongolian civil aviation company "MIAT" - with its own security service/department, the Mongol-Russian joint society "Ulaanbaatar Railway - with its security paramilitary service/department, many fortune companies such as MCS Group, MAX Group, MAC Corporation and HUNNU Group - all having their own security departments [4].

While the security services of the Mongolian civil airlines "MIAT" and of the "Ulaanbaatar Railway" are the security services belonging to these state owned companies as a part of their organizational structures, the peculiar feature of the security services or units of MCS Group, MAX Group, MAC Corporation and HUNNU Group, is that they are operating as the daughtercompanies of these groups concerned to ensure their security and safety [5]. All these proprietary security services are different from the contract security service since they are operating at a more advanced level in terms of their legal environment, security ensuring guidelines and duties, sphere of activities, organizational profile, budget and funding sources, equipment, technology, tools or weaponry.

\section{The Airport Security Service}

\section{THE PROPRIETARY SECURITY}

The security service of the Chinggis Khaan Airport of the Mongolian civil aviation company MIAT was set up in 1996. In the past or during the socialism, the airport security was ensured by the state security bodies or by the units of the internal troops under the General Militia Directorate. / Former name of National Police Agency [6].

The legal basis, the guidelines and the principles of operations and the profile of the airport security service of the Chinggis Khaan Airport were specified by in the National Programme for Ensuring the Security and Safety of Civil Aviation approved by the Mongolian Government Resolution No.175 of 2007.

While the airport security service and safety is issued the license for carrying out security operations by the General Department of Civil Aviation for a term of 3 years, in the case of the contract security units, their license for conducting security activities is issued by the police organization for a term of $1[6]$. 
The civil aviation security service or the airport security service is entrusted with the duties and obligations to issue the passes/cards authorizing to enter the prohibited or protected zones of the airport, to provide security searches and checks with regard to persons entering the prohibited zones, to passengers and their hand carried staffs and luggage, to mailed parcels, packages and the other luggage and staffs. In addition to it, the airport security service is required to train its own staff under the training program on civil aviation security and safety procedures and measures in accordance with established standards and to strictly follow the requirements that the security checks be conducted exclusively by those specially trained professional staff officers [6].

The security and safety of the protected zone and area must be ensured through the erection of fences, barriers and the installation of alarm alert system, of devices for proper lighting and of camera control system. The airport security staff officers should be recruited through the special selection procedures based on their application packages. The airport security officers in charge of security checking operations must undergo a special training course on civil aviation security requirements and procedures and give proper professional certificates [6].

What is the specific feature of the airport security service is that it develops its own training program in conformity with the training program on the civil aviation security and safety as approved by the chairman of the General Department of Civil Aviation and conducts such training activities independently.

For the purpose of implementing their duties, the staff officers of the airport security service must be provided, in accordance with the law on the contract private security, with trained dogs, fire arms and special security tools and specific feature uniforms proper for the specifics of their service duty.

\section{The Mongol-Russian Joint Stock Society “Ulaanbaatar Railway - Its Railway Security Paramilitary Service}

As about the history of this service, the railway paramilitary security service was established in 1949 by the joint-resolution of the governments of the USSR and MPR. The railway security service carries out its activities under the guidance of the chairman of the Directorate of the Ulaanbaatar Railway. The chief of the railway security service is appointed and discharged by the chairman of the Directorate of the Ulaanbaatar Railway. The railway security service has its branches in central and local areas. The staff officers of the railway security service should be citizens of Mongolia who are recruited in conformity with the rules and procedures as approved by the chairman of the Directorate of the Ulaanbaatar Railway. What is characteristic for the railway security service is the fact that the officers of the railway security service swear an oath [7]. As of today, the Ulaanbaatar railway paramilitary security service employs some 450 to 500 staff officers.

The activities of the railway paramilitary security service are conducted within the framework of the "Statute of the Railway Paramilitary Security Service" approved by the Government Resolution of 2 January 1997 in conformity with "the Law on the Security of Railway Transportation of Mongolia" [8].

In accordance with this statute, the duties and responsibilities of the railway paramilitary security service are to protect the railway facilities, transported goods and luggage from random incursions, to secure fire safety and exercise control over it in the railway organization, to fight fires and to support the measures undertaken for maintaining order on 
territories under the railway possession, at railway stations, railway terminals and other facilities. What is peculiar to the railway paramilitary security service as compared to the other security service entities is the fact that the railway paramilitary security service exercise control over the enforcement of fire safety laws and regulations by the central terminal station, by the railway stations and by the other facilities of the railway organization.

The officers of the railway security service are provided with the official uniforms and identification discs and badges to be decided by the railway authority and for use while on duty. The railway security service should use its own logo and letterhead as established by the rules concerned [7].

\section{THE CONTRACT SECURITY}

Nowadays, the second category of the private security already plays a predominant role in the security service sector of Mongolia [9].

What is the peculiarity of the operations of the contract security companies is that those contract security firms and entities provide the security and safety services based on the individual contractual agreements concluded or signed with their clients and that they are selffinanced by the profits they earn from the fees of their security and safety services provided to their clients and that they are also committed to compensate their clients for damages and losses inflicted by their faults or mistakes.

According to the statistics collected by the Department of Public Security of the National Police Agency, the number of registered and operational contract security units, as of February 2012, was as follows: -345 contract security units in Ulaanbaatar and 35 contract security units in local areas, making a total of 370; and as of 2013, -there were 345 contract security units in Ulaanbaatar and 35 contract security units in local areas; and as of 2014, - there were 327 contract security units in Ulaanbaatar and 35 contract security units in local areas making a total of 362 units; and as of 2015- there were 230 contract security in municipal areas and 35 contract security units in local areas as a total of 265 contract security units [10].

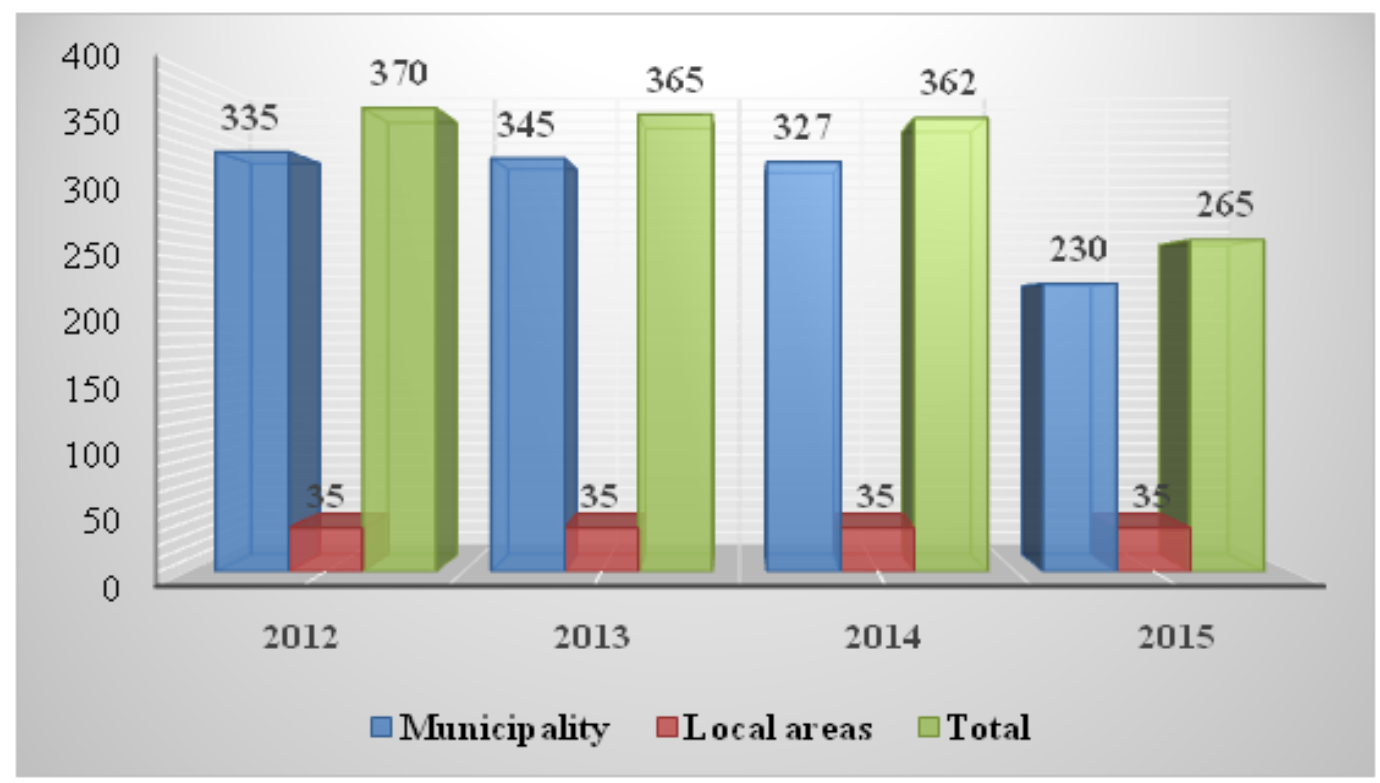

Fig. 1. Total of Contract Security Companies Registered with Police Organizations [10] 
The above quoted statistics show a tendency of the decrease in the number of the contract security companies registered with the police organization. According to our findings, the reason of such a decrease is due to the current world economic crisis that affected the national economy of Mongolia causing the sudden fall of prices of exported minerals like coal, gold and copper. As such, the financial standing of the business entities organizations have become weakened to use the contract security service units resulting in a decrease in the number of the contract security service units or, for the same reason, some of the former contract security units became defaulted and bankrupted to be forced to cease their operations or to be integrated within the structure of the other contract service firms or units [9].

\section{The Registration of Contract Security Company}

In conformity with the Article 7 of the Law on Contracted Private Security Service of Mongolia, the registration of the private security companies is conducted by the municipal and local police organizations.

Those legal entities wishing to carry out the contract security service activities should submit to the municipal and local police authorities the following documents: 1) The application wishing to carry out security service activities; 2) The original of the certificate of the given legal entity and the notarized copy thereof; 3) The recommendation letters issued by the correspondent bank and the tax authority acknowledging the financial capacity of the given legal entity to operate on the self- financing and self-supporting basis; 4) in the case of a legal entity with foreign investments, the original and extended agreement there on and the notarized copy thereof; 5) The documents regarding the staff personnel, the charter organizational structure of the given legal entity and the original license authorizing the given legal entity to use the radio frequency and to operate the radio transmission station and the notarized cope thereof; 6) The correct curriculum vitae of each of its staff officers, their health reports and the documentary evidence and certificates, proving that more than 5 staff officers were trained in a due course; 7) The police letters on the criminal records of each of its staff officers; 8) The list and specifications of each of special tools required for conducting security operations like the rifles with rubber and plastic bullets, rubber or electric shock truncheons, hand and finger cuffs, tear gas spray devices and the other protective devices, trained dogs; 9) The designs and pictures of the uniforms for security officers, the pictures of identification badges, the 3-profile photos showing the designs and shapes of uniforms; 10) The specifications for camera and alarm system devices to be used. The number of patrol cars and their state registration numbers etc... (Article 7.2).

In 2015, according to the statistics, the number of the private contract security entities conducting their activities in the capital city and in local areas and the number of their staff personnel were as follows: In the capital city: - 230 private contract security entities with a total of 4,040 staff officers; In the local areas: - 35 private contract security entities with a total of 828 staff officers; That means that, at the national level, a total of 265 private contract security entities with a total of 4,868 staff officers were conducting private security activities $[10]$.

One of the prerequisites for ensuring the operations of the private security service entities on a sustainable basis is the provision of the proper office facilities for them. The current research shows that the provision of office facilities for the private contract security entities where they could be able to normally work should be an immediate task to be solved at the national level. 
The findings as reported by the Capital City Professional Control Department based on its inspections of the private contract security entities in 2013 in terms of their office facilities are as follows: 17 entities or 5.6 percent out of the total 290 of the private contract security entities inspected had conducted their activities in the rented office; 240 entities or 82.7 percent of out of the total 290 of the private contract security entities inspected had their own office and 33 private security entities or 11.3 percent of out of the total 290 of the private contract security entities inspected did not have their own office.

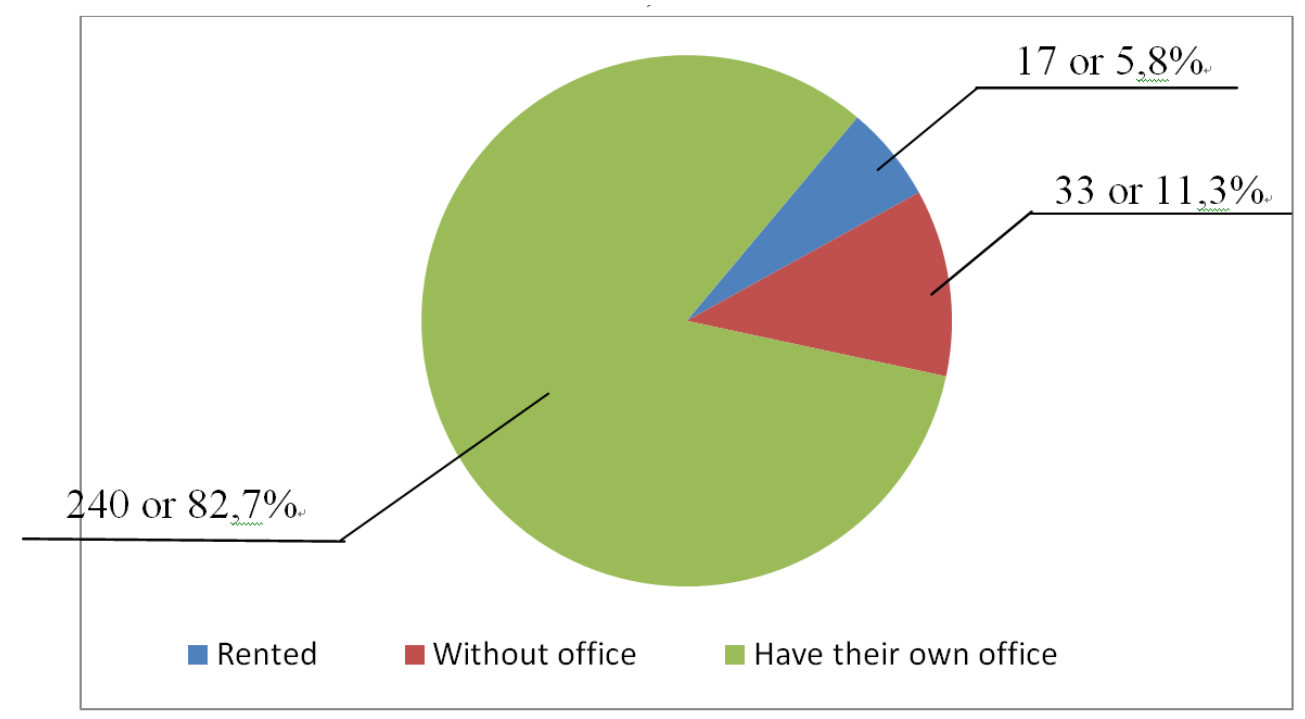

Fig. 2. The Status Business Office Availability of Private Security Companies, 2013 [10]

In addition to it, most of the private security entities had the facilities only limited to office rooms not having any available spaces for conducting their training activities, for sporting or recreation events. If some spaces were available, they could not meet the requirements, as showed the reports concerned and the results of our research findings. All these office shortcomings are attributable to the extremely high office space rental prices or to the poor financial capacities of the private contract security entities.

\section{The control over the private security companies by the police organizations and by the authorities}

The Article 21 of the Law on Contracted Private Security Service stipulates that "The police organization is authorized to exercise the control over the compliance of the activities of the security services with the laws and regulations and to require the security services to submit the documents and explanatory notes as needed for this purpose". This indicates that the control duties of the police organizations are limited to the registration of the security service entities, to require from them the documents and reports regarding their operations - a case that is far from being satisfactory. As such, due to the lack of the professional control over the operations of the contract security service entities without any power and authority to inspect them or to instruct them or to make them accountable for the failure to duly fulfill their responsibilities, there is a general tendency leading to the increase in the number of contract security services entities carrying out their activities without the registered licenses or not to conduct their activities despite their licenses and registrations.

In addition to it, there is a lack of the competence or discrepancy in the control and inspection duties of the professional control department, because the state professional control 
organization is exercising the control and inspection activities under "the Law on State Control and Inspection" and, as such, it exercises the professional control and inspections within the framework of its common duties and responsibilities to exercise control only over the enforcement of laws and legal regulations designed for ordinary businesses. Furthermore, the control and inspection duties of the professional control organizations and that of the police organizations are overlapping and being conducted without any professional guidance and control mechanism in many aspects that are required to control and inspect the activities of the private security service entities. It should be noted as well the fact that the laws and the regulations relating the contract private security service entities are conflicting with each other being without any strict inter-active legal force and relevance [11].

There is another gap in the legal regulations for the operations of the private security service entities, as according to the Law On Contracted Private Security Service the police organization is not authorized to make those contract security officers or entities that are found guilty or are convicted of crimes to become accountable for the infraction of laws and regulations and for the breach of their administrative responsibility, instead only the court is authorized thereto. But, until now, no cases of punishments relevant to the failure by private security service entities and by their officers to meet their administrative responsibility were solved by court decisions.

\section{The types of activities carried out by the contract security service companies}

There are 3 types of activities that are conducted by the private contract security entities for the purpose of ensuring the security of the property and the facilities of their clients in conformity with the Section 3.1.1 of the Article 3 of the Law on Contracted Private Security Service", as follows:

- Security service and safety implemented by security officers in their person (by contingent)

- Security service and safety ensured by the alarm system (Electronic security)

- Security service and safety ensured during the private events (Private event security).

According to a survey conducted in 2013, the proportion of the above 3 types of activities carried out by the private contract security entities as inspected and reported by the professional control organization was as follows: A total of 257 the private contract security entities or 88.6 percent of the total of the private contract security entities carried out their activities with the physical involvement of their staff officers in their person; 31 private contract security entities or 10.6 percent of the total of the private contract security entities ensured the security operations based on alarm system; only 2 private contract security entities or 0.6 percent of the total of the private contract security entities carried out their activities for ensuring the security and safety during the events (event security) like concerts and the other public events and mass gatherings etc.). 


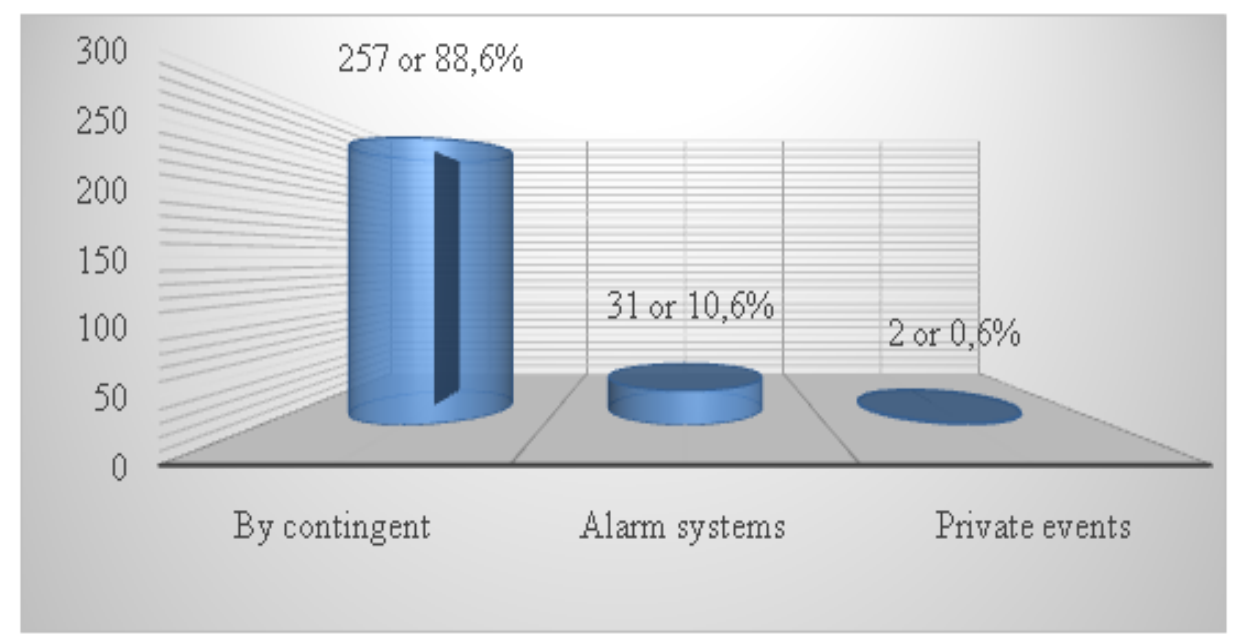

Fig. 3. The Type of Contract Security Operations

\section{The facilities and installations placed under security protection}

Except those facilities, installations and organizations of extreme importance that are placed under the state special security protection, all the other facilities, installations and organizations are placed under the private contract security service entities under contracts in line with market forces. As such, these facilities, installations and organizations placed under the security protection implemented by the private contract security service entities are, for example, some state organizations, national private business entities and business entities with foreign investments, publicly owned property and assets, major auto parking stations, residential towns, privately owned lands, private premises and houses, the mining fields run by mining companies, industrial plants and factories, banks, financial institutions, public entertainment and service organizations and facilities like theaters, museums and stadium, private clinics and hospitals, trade centers (supermarkets) etc.. Under the effect of the development of the market relations, the number of entities and facilities placed under the state security protection is gradually decreasing from year to year to be placed under the protection of the private contract security service entities. That means that the number of facilities and entities falling under the protection of the private contract security service entities is expected to grow in a near future [12].

\section{CONCLUSION}

The main objective of this study was to analyse current condition of private security in Mongolia and findings detailed in the study showed that, in general, the security service in Mongolia is being developed with the two types of security service including the proprietary service and the contract service.

Within the framework of the practical activities in matters of the registration of the private security service entities there is a need to build a nation widely unified date base for the registration of the private security service entities to be renewed and revised on a regular basis.

In addition to it, there is a need to put on the data base all the data and information on the types of the activities of the private security service entities, their organizational structure, staff personal, equipment and their technical facilities and the locations of the facilities placed under their security protection and on any other changes, including their discharged officers and any other required information, so as all these data and information be made available and accessible for the official use at the national level. 
Despite the fact that the legal regulations governing the private security industry in Mongolia are in conformity with the established international standards and practices, still there is an imperative need to enhance the legal regulations of private security based on findings in this study.

\section{References}

1. Enkhbold, B., \& Hwang, E. (2014). Crime trend and emerging crime types after democratization in modern Mongolia: The effect of social transition and urbanization. Journal of Terrorism Studies. 4. 238-239.

2. Mongolia National Police Agency (2012). Report on Legal Framework of Contract Private Security Service. Ulaanbaatar, Mongolia: The National Police Agency.

3. Khurelbaatar, T. (2014). Some Issues of the Protection of the Object. Ulaanbaatar, Mongolia: Munkhiin Useg Press.

4. Dialy News History of Private Security in Mongolia. 2015.12.16. 302(5251): Ulaanbaatar, Mongolia. Newspaper.

5. Batjav, B., \& Davaadorj, D. (2009). Grounds of the Contracted Private Security Service Activity. Ulaanbaatar, Mongolia: Bit Press Publishing Company

6. Resolution of Government (2007). The National Programme for Ensuring the Security and Safety of Civil Aviation. Ulaanbaatar, Mongolia: Government Printing Office.

7. Resolution of Government (1997). Statute of the Railway Paramilitary Security Service .Ulaanbaatar, Mongolia: Government Printing Office.

8. Chuluunbat, B. (2014). Protection of Object. . Ulaanbaatar, Mongolia: Soyombo Press.

9. Purev, B. (2011). History of the Development of the Legal Regulations for Police Organizations: The Foundation of the Legal Basis for Police Organization. Compilation of Report of Conference. The National Police Agency printing Office.

10. Mongolia National Police Agency (2015). Report on Legal Framework of Contract Private Security Service. Ulaanbaatar, Mongolia: The National Police Agency.

11. Amarsanaa, J. (2009). Constitutionalism and Constitutional Review in Mongolia. Ulaanbaatar, Mongolia: The National Legal Institute Press.

12. Batshakhian, O. (2012). Mongolians in the 20th century. Ulaanbaatar, Mongolia: Mon Sudar Pres 